\title{
Novel ferrocenylphosphino sulfonates: Synthesis, crystal structure and preliminary application as ligands in aqueous catalysis
}

Diego Sierra, ${ }^{\text {a }}$ Claudia Contreras, ${ }^{a}$ Javier Francos, ${ }^{b}$ Johana Gómez, ${ }^{\mathrm{c}}$ Victorio Cadierno* ${ }^{\mathrm{b}}$

a Laboratorio de Química Organometálica y Catálisis, Instituto de Química y Bioquímica, Facultad de Ciencias, Universidad de Valparaíso, Av. Gran Bretaña 1111, Valparaíso, Chile.

${ }^{b}$ Laboratorio de Compuestos Organometálicos y Catálisis (Unidad Asociada al CSIC), Centro de Innovación en Química Avanzada (ORFEO-CINQA), Departamento de Química Orgánica e Inorgánica, IUQOEM, Universidad de Oviedo, Julián Clavería 8, E-33006 Oviedo, Spain.

${ }^{c}$ Laboratorio de Química Organometálica, Instituto de Química, Facultad de Ciencias, Pontificia Universidad Católica de Valparaíso. Av. Universidad 330, Valparaíso, Chile.

\begin{abstract}
The synthesis and characterization of three novel ferrocenylphosphino sulfonates, namely $\left(\eta^{5}-\mathrm{C}_{5} \mathrm{H}_{3} \mathrm{PR}_{2}\left(\mathrm{SO}_{3} i-\mathrm{Pr}\right)\right) \mathrm{Fe}\left(\eta^{5}-\mathrm{C}_{5} \mathrm{H}_{5}\right)(\mathrm{R}=\mathrm{Ph}, p$-Tol, Cy), is presented along with their solid-state X-ray crystal structures. Preliminary studies on the utility of these compounds as auxiliary ligands in aqueous catalysis, in particular for the rutheniumcatalyzed ortho-arylation of 2-phenylpyridine, are also discussed.
\end{abstract}

Keywords: Ferrocenylphosphines; Phosphine sulfonates; Ruthenium; Aqueous catalysis; Ortho-arylations.

\footnotetext{
* Corresponding authors. E-mail addresses: diego.sierra@uv.cl (D. Sierra), vcm@uniovi.es (V. Cadierno)
} 


\section{Introduction}

Ferrocenylphosphines are classical ligands in coordination and organometallic chemistry, and the resulting transition-metal complexes have been widely employed as catalysts in a huge number of chemical transformations [1]. However, despite the growing interest in developing metal catalysis in environmentally friendly aqueous media [2], the use of this type of ligands in aqueous catalysis has been largely neglected [3], due probably to the high hydrophobic character of the ferrocenyl skeleton and the synthetic difficulties to functionalize the cyclopentadienyl rings with polar or charged hydrophilic groups. As a matter of fact, very few examples of water-soluble ferrocenylphosphines can be found in the literature. In this regard, the works by Štěpnička and co-workers on the design and catalytic uses of ferrocenylphosphines functionalized with hydrophilic amide groups merit to be highlighted [4]. Karasik, HeyHawkins and co-workers also reported the preparation of a series of water-soluble aminomethyl(ferrocenylmethyl)phosphines and their coordination to palladium and platinum fragments, but the resulting complexes were not tested in catalysis [5].

As exemplified by the well-known TPPMS ((msulfonatophenyl)diphenylphosphino sodium salt), the introduction of sulfonate groups represents one of the most powerful strategies to transform classical phosphines into water-soluble ligands $[3,6]$. In this context, although a variety of mono- and 1,1'disulfonated ferrocene derivatives are presently known [7], efforts to introduce sulfonate functionalities on one of the cyclopentadienyl rings of a ferrocenylphosphine have been so far very scarce. In particular, to the best of our knowledge, the available examples are limited to some diaryl- and dialkylphosphinoferrocene sulfonic acids, i.e. $\left(\eta^{5}-\mathrm{C}_{5} \mathrm{H}_{3} \mathrm{PR}_{2}\left(\mathrm{SO}_{3} \mathrm{H}\right)\right) \mathrm{Fe}\left(\eta^{5}-\mathrm{C}_{5} \mathrm{H}_{5}\right)(\mathrm{A}$ in Figure 1$)$, reported by the groups of Chen and Erker [8]. Starting from these sulfonic acids, the authors carried out the synthesis of 
some palladium phosphino-sulfonate complexes, which proved to be catalytically active in alternated copolymerization reactions, albeit with moderated activity and in a nonaqueous environment. In the context of their studies directed to the induction of planar chirality, Metallinos and Snieckus also reported the preparation of different stereoisomers of the ferrocenylphosphino sulfonate $\left(\eta^{5}-\mathrm{C}_{5} \mathrm{H}_{3} \mathrm{PPh}_{2}\left(\mathrm{SO}_{3}-(-)-\right.\right.$ menthyl) $) \mathrm{Fe}\left(\eta^{5}-\mathrm{C}_{5} \mathrm{H}_{5}\right)\left(\mathbf{B}\right.$ and $\mathbf{B}^{\prime}$ in Figure 1), as well as the X-ray crystal structure of one them [9]. The authors also tested $\mathbf{B}$ as ligand for the enantioselective palladiumcatalyzed allylic substitution of phenylcinnamyl acetate, using again an organic solvent $\left(\mathrm{CH}_{2} \mathrm{Cl}_{2}\right)$ as the reaction medium.

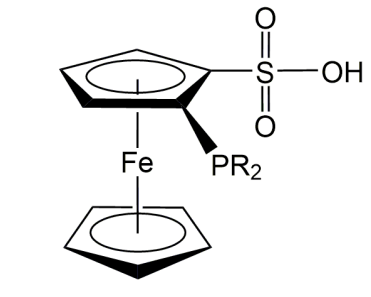

$\mathrm{R}=$ aryl or alkyl group A

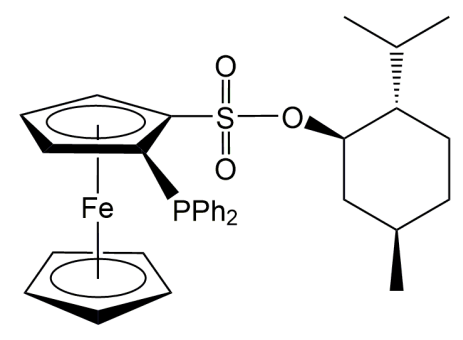

B

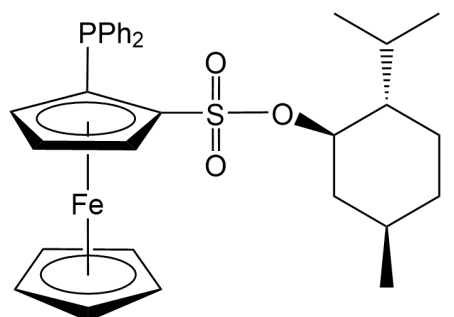

$B^{\prime}$

Figure 1. Structure of the ferrocenylphosphines $\mathbf{A}$ and $\mathbf{B} / \mathbf{B}^{\prime}$.

With these precedents in mind, we decided to synthesize new ferrocenylphosphino sulfonate derivatives and explore their potential utility as ligands for aqueous catalysis. In particular, we present herein the preparation and characterization of three representatives, as well as a preliminary study of their involvement in the rutheniumcatalyzed arylation of 2-phenylpiridine in water.

\section{Experimental}

\subsection{General information}


All the reagents were obtained from commercial suppliers and used as received, with the exception of the ferrocenyl derivatives $\mathbf{1}$ [10], 2 [10] and $\mathbf{3}$ [9], and the ruthenium complexes $\left[\left\{\operatorname{RuCl}(\mu-\mathrm{Cl})\left(\eta^{6} \text {-arene) }\right\}_{2}\right]\right.$ (arene $=p$-cymene [11], $\mathrm{C}_{6} \mathrm{H}_{6}[12]$, $\left.\mathrm{C}_{6} \mathrm{Me}_{6}[11]\right),\left[\mathrm{RuCl}_{2}\left(\mathrm{PPh}_{3}\right)_{3}\right]$ [13] and cis-[ $\left.\mathrm{RuCl}_{2}(\mathrm{DMSO})_{4}\right]$ [14], which were prepared following previously reported methodologies. All reactions were carried out under argon atmosphere using standard Schlenk techniques. Organic solvents were purified following standard procedures [15]. NMR spectra were recorded with a Bruker AV300 and AV400 spectrometers. ${ }^{1} \mathrm{H}$ and ${ }^{13} \mathrm{C}\left\{{ }^{1} \mathrm{H}\right\}$ NMR chemical shifts were referenced using the residual solvent resonances, and ${ }^{31} \mathrm{P}\left\{{ }^{1} \mathrm{H}\right\}$ NMR chemical shifts were referenced to $85 \% \mathrm{H}_{3} \mathrm{PO}_{4}$ as external standard. The mass spectrums of compounds 4 a-c were obtained on a Shimadzu QP5050 instrument with a direct injection capability for non-volatile samples at the Facultad de Ciencias, Pontificia Universidad Católica de Valparaíso, while their elemental analyses were provided by the Analytical Service of the Instituto de Investigaciones Químicas (IIQ-CSIC) of Sevilla.

2.2. General procedure for the synthesis of compounds $\left(\eta^{5}-\mathrm{C}_{5} \mathrm{H}_{3} \mathrm{PR}_{2}\left(\mathrm{SO}_{3} \mathrm{i}-\mathrm{Pr}\right)\right) \mathrm{Fe}\left(\eta^{5}\right.$ $\left.C_{5} H_{5}\right)(R=P h(4 a) ; R=p$-Tolyl $(4 \boldsymbol{b}) ; R=C y(4 c))$.

In a Schlenk flask filled with Ar and equipped with a stir bar, $200 \mathrm{mg}$ of isopropyl ferrocene sulfonate $3(0.65 \mathrm{mmol})$ were dissolved in $10 \mathrm{~mL}$ of dry THF. The resulting solution was cooled to $-78{ }^{\circ} \mathrm{C}$ and then $0.56 \mathrm{~mL}$ of $s e c-\mathrm{BuLi}(1.4 \mathrm{M}$ in cyclohexane; $0.78 \mathrm{mmol}$ ) were slowly added via cannula. The red reaction mixture was stirred for $1 \mathrm{~h}$ at $-78{ }^{\circ} \mathrm{C}$ and, after that time, the respective chlorophosphine $\mathrm{R}_{2} \mathrm{PCl}(\mathrm{R}=$ $\mathrm{Ph}, p$-Tol, Cy) was added $(0.78 \mathrm{mmol})$. The mixture was then left to reach r.t. and quenched with a saturated solution of $\mathrm{NH}_{4} \mathrm{Cl}$; the organic phase was separated and the aqueous one extracted with two portions of diethyl ether $(10 \mathrm{~mL})$. The organic phases 
were mixed, dried over $\mathrm{MgSO}_{4}$ and evaporated to dryness. The residue was purified by column chromatography over $\mathrm{SiO}_{2}$, using a mixture of hexane:ethyl acetate: $\mathrm{Et}_{3} \mathrm{~N}$ (90:9:1) as eluent, to give the new ferrocenylphosphino sulfonates $4 \mathbf{a}$ (197 $\mathrm{mg} ; 0.49$ $\mathrm{mmol} ; 75 \%)$, $4 \mathbf{b}(270 \mathrm{mg} ; 0.52 \mathrm{mmol} ; 80 \%)$ and $4 \mathbf{c}(200 \mathrm{mg} ; 0.4 \mathrm{mmol} ; 61 \%)$ as yellow-orange solids.

4a: ${ }^{1} \mathrm{H}$ NMR (400 MHz, $\left.\mathrm{CDCl}_{3}\right) \delta$ 7.56-7.52 (m, 2H), 7.40-7.38 (m, 3H), 7.29$7.22(\mathrm{~m}, 5 \mathrm{H}), 4.99(\mathrm{~m}, 1 \mathrm{H}), 4.57(\mathrm{sept}, J=6.2 \mathrm{~Hz}, 1 \mathrm{H}), 4.51(\mathrm{~m}, 1 \mathrm{H}), 4.35(\mathrm{~s}, 5 \mathrm{H}), 3.90$ $(\mathrm{m}, 1 \mathrm{H}), 1.06(\mathrm{~d}, J=6.2 \mathrm{~Hz}, 3 \mathrm{H}), 0.86(\mathrm{~d}, J=6.2 \mathrm{~Hz}, 3 \mathrm{H}) \mathrm{ppm} .{ }^{13} \mathrm{C}\left\{{ }^{1} \mathrm{H}\right\} \mathrm{NMR}(75$ $\left.\mathrm{MHz}, \mathrm{CDCl}_{3}\right) \delta 138.3(\mathrm{~d}, J=12.5 \mathrm{~Hz}), 137.0(\mathrm{~d}, J=12.6 \mathrm{~Hz}), 134.9(\mathrm{~d}, J=21.8 \mathrm{~Hz})$, $133.1(\mathrm{~d}, J=20.1 \mathrm{~Hz}), 129.4(\mathrm{~s}), 128.4(\mathrm{~s}), 128.3(\mathrm{~d}, J=7.4 \mathrm{~Hz}), 128.2(\mathrm{~d}, J=6.7 \mathrm{~Hz})$, $89.0(\mathrm{~d}, J=21.2 \mathrm{~Hz}), 78.1(\mathrm{~d}, J=20.0 \mathrm{~Hz}), 76.1(\mathrm{~s}), 73.8(\mathrm{~s}), 72.1(\mathrm{~s}), 71.4(\mathrm{~s}), 22.9(\mathrm{~s})$, 22.5 (s) ppm. ${ }^{31} \mathrm{P}\left\{{ }^{1} \mathrm{H}\right\}$ NMR (121 MHz, $\left.\mathrm{CDCl}_{3}\right) \delta-22.0$ (s) ppm. Elemental analysis (\%) calcd for $\mathrm{FeC}_{25} \mathrm{H}_{25} \mathrm{O}_{3} \mathrm{PS}$ (492.35 g/mol): C 60.99, H 5.12; found: C 61.12, H 5.03. MS (based on $\left.{ }^{56} \mathrm{Fe}\right) \mathrm{m} / z: 492\left(\mathrm{M}^{+}\right) ; 450\left(\mathrm{M}^{+}-i\right.$-Pr $) ; 370\left(\mathrm{M}^{+}-i-\mathrm{Pr}-\mathrm{SO}_{3}\right)$.

4b: ${ }^{1} \mathrm{H}$ NMR $\left(300 \mathrm{MHz}, \mathrm{CDCl}_{3}\right) \delta 7.43(\mathrm{~m}, 2 \mathrm{H}), 7.23-7.03(\mathrm{~m}, 6 \mathrm{H}), 4.97(\mathrm{~s}, 1 \mathrm{H})$, 4.55 (sept, $J=6.2 \mathrm{~Hz}, 1 \mathrm{H}), 4.49$ (s, 1H), 4.34 (s, 5H), 3.92 (s, 1H), 2.39 (s, 3H), 2.32 (s, $3 \mathrm{H}), 1.07(\mathrm{~d}, J=6.2 \mathrm{~Hz}, 3 \mathrm{H}), 0.87(\mathrm{~d}, J=6.2 \mathrm{~Hz}, 3 \mathrm{H}) \mathrm{ppm} .{ }^{13} \mathrm{C}\left\{{ }^{1} \mathrm{H}\right\} \mathrm{NMR}(75 \mathrm{MHz}$, $\left.\mathrm{CDCl}_{3}\right) \delta 139.4(\mathrm{~s}), 138.3(\mathrm{~s}), 134.9(\mathrm{~d}, J=21.7 \mathrm{~Hz}), 134.8(\mathrm{~d}, J=10.1 \mathrm{~Hz}), 133.5(\mathrm{~d}, J$ $=10.6 \mathrm{~Hz}), 133.2(\mathrm{~d}, J=20.4 \mathrm{~Hz}), 129.2(\mathrm{~d}, J=7.6 \mathrm{~Hz}), 128.9(\mathrm{~d}, J=7.0 \mathrm{~Hz}), 88.9(\mathrm{~d}$, $J=21.0 \mathrm{~Hz}$ ), $78.7(\mathrm{~d}, J=20.1 \mathrm{~Hz}), 76.1(\mathrm{~s}), 73.8(\mathrm{~s}), 72.7$ (s), $71.5(\mathrm{~s}), 23.0$ (s), 22.6 (s), 21.4 (s), 21.3 (s) ppm. ${ }^{31} \mathrm{P}\left\{{ }^{1} \mathrm{H}\right\}$ NMR (121 MHz, $\left.\mathrm{CDCl}_{3}\right) \delta-25.0$ (s) ppm. Elemental analysis (\%) calcd for $\mathrm{FeC}_{27} \mathrm{H}_{29} \mathrm{O}_{3} \mathrm{PS}(520.40 \mathrm{~g} / \mathrm{mol})$ : C 62.32, $\mathrm{H}$ 5.62; found: $\mathrm{C}$ 62.17, H 5.70. MS (based on $\left.{ }^{56} \mathrm{Fe}\right) m / z: 520\left(\mathrm{M}^{+}\right) ; 478\left(\mathrm{M}^{+}-i\right.$-Pr); $398\left(\mathrm{M}^{+}-i-\mathrm{Pr}-\mathrm{SO}_{3}\right)$.

4c: ${ }^{1} \mathrm{H}$ NMR $\left(300 \mathrm{MHz}, \mathrm{CDCl}_{3}\right) \delta 4.92(\mathrm{sept}, J=6.3 \mathrm{~Hz}, 1 \mathrm{H}), 4.86(\mathrm{~s}, 1 \mathrm{H}), 4.54$ (s, 1H), $4.38(\mathrm{~s}, 5 \mathrm{H}), 4.36(\mathrm{~s}, 1 \mathrm{H}), 2.40-1.11(\mathrm{~m}, 22 \mathrm{H}), 1.41(\mathrm{~d}, J=6.2 \mathrm{~Hz}, 3 \mathrm{H}), 1.25$ (d, 
$J=6.3 \mathrm{~Hz}, 3 \mathrm{H}) \mathrm{ppm} .{ }^{13} \mathrm{C}\left\{{ }^{1} \mathrm{H}\right\} \mathrm{NMR}\left(75 \mathrm{MHz}, \mathrm{CDCl}_{3}\right) \delta 87.9(\mathrm{~d}, J=19.1 \mathrm{~Hz}), 80.8(\mathrm{~d}$, $J=32.7 \mathrm{~Hz}$ ), 77.2 (s), 76.2 (s), 74.0 (d, $J=5.2 \mathrm{~Hz}), 72.2$ (s), 72.0 (s), 70.9 (s), 36.9 (d, $J$ $=16.0 \mathrm{~Hz}), 34.7(\mathrm{~d}, J=16.5 \mathrm{~Hz}), 32.4(\mathrm{~d}, J=20.2 \mathrm{~Hz}), 31.3(\mathrm{~d}, J=17.0 \mathrm{~Hz}), 29.7(\mathrm{~d}, J$ $=8.3 \mathrm{~Hz}), 28.7(\mathrm{~d}, J=10.7 \mathrm{~Hz}), 27.7(\mathrm{~d}, J=12.8 \mathrm{~Hz}), 27.6(\mathrm{~d}, J=12.8 \mathrm{~Hz}), 27.3(\mathrm{~d}, J=$ $8.6 \mathrm{~Hz}), 27.2$ (d, $J=8.6 \mathrm{~Hz}), 26.4(\mathrm{~s}), 26.3$ (s), 23.6 (s), 23.0 (s) ppm. ${ }^{31} \mathrm{P}\left\{{ }^{1} \mathrm{H}\right\} \mathrm{NMR}$ (121 MHz, $\left.\mathrm{CDCl}_{3}\right) \delta-12.0$ (s) ppm. Elemental analysis (\%) calcd for $\mathrm{FeC}_{25} \mathrm{H}_{37} \mathrm{O}_{3} \mathrm{PS}$ (504.44 g/mol): C 59.53, H 7.39; found: C 59.39, H 7.42. MS (based on ${ }^{56} \mathrm{Fe}$ ) m/z: 504 $\left(\mathrm{M}^{+}\right) ; 462\left(\mathrm{M}^{+}-i-\mathrm{Pr}\right) ; 380\left(\mathrm{M}^{+}-i-\mathrm{Pr}-\mathrm{SO}_{3}\right)$.

\subsection{General procedure for the ruthenium-catalyzed arylation of 2-phenylpyridine.}

The corresponding ruthenium(II) precursor (5 $\mathrm{mol} \%$ of $\mathrm{Ru}$ ), the respective ferrocenyl ligand 4a-c $(5 \mathrm{~mol} \%)$ and water $(1 \mathrm{~mL})$ were introduced in a Teflon-capped sealed tube filled with Ar and equipped with a magnetic stir bar. The mixture was stirred for 5 minutes at r.t. and then $\mathrm{K}_{2} \mathrm{CO}_{3}(0.5 \mathrm{mmol})$, 2-phenylpiridine $(0.5 \mathrm{mmol})$ and the bromobenzene $(0.75 \mathrm{mmol})$ were added. The dark red reaction mixture was subsequently heated at $100{ }^{\circ} \mathrm{C}$ for $24 \mathrm{~h}$. After this time, the aqueous reaction mixture was cooled to room temperature and extracted with $\mathrm{Et}_{2} \mathrm{O}(4 \times 5.0 \mathrm{~mL})$. The combined organic extracts were washed with brine, dried over anhydrous $\mathrm{MgSO}_{4}$, filtered and evaporated to dryness. The oiled residue was dissolved in $\mathrm{CDCl}_{3}$, and the concentration of the reagents and product was determined by ${ }^{1} \mathrm{H}$ NMR spectroscopy through the integration of the signals of the $\mathrm{C}(5)-\mathrm{H}$ pyridinic protons.

2.4. X-Ray crystal structure determination of compounds $\left(\eta^{5}-\mathrm{C}_{5} \mathrm{H}_{3} \mathrm{PR}_{2}\left(\mathrm{SO}_{3} \mathrm{i}-\mathrm{Pr}\right)\right) \mathrm{Fe}\left(\eta^{5}-\right.$ $\left.C_{5} H_{5}\right)(R=P h(4 a) ; R=p-T o l y l(4 b) ; R=C y(4 c))$. 
Orange-red crystals of 4a-c suitable for X-ray diffraction analysis were obtained from saturated solutions of the compounds in hexane/ethyl acetate $(9: 1 \mathrm{v} / \mathrm{v})$ mixtures. The most relevant crystal and refinement data are collected in Table 1. Data collections were performed on an Oxford Diffraction Xcalibur Nova single crystal diffractometer using $\mathrm{Cu}-\mathrm{K} \alpha$ radiation $(\lambda=1.5418 \AA)$. Images were collected at a fixed crystal-todetector distance of $62 \mathrm{~mm}$, using the oscillation method with $1.3^{\circ}$ oscillation $(\mathbf{4 a}, \mathbf{c})$ or $1.2^{\circ}(\mathbf{4 b})$ and 2.5-7.5 $\mathrm{s}$ variable exposure time per image for $\mathbf{4 a}, 2-5 \mathrm{~s}$ for $\mathbf{4 b}$, and 3-10 $\mathrm{s}$ for 4c. Data collection strategy was calculated with the program CrysAlis Pro CCD [16]. Data reduction and cell refinement was performed with the program CrysAlis Pro RED [16]. Empirical absorption correction was applied using the SCALE3 ABSPACK algorithm as implemented in the program CrysAlis Pro RED [16]. In all the cases, the software package WINGX was used for space group determination, structure solution, and refinement [17]. The structures were solved by direct methods and conventional Fourier techniques, and refined by full-matrix least-squares on $\mathrm{F}^{2}$ using SHELXL2014 [18]. During the final stages of the refinements, all the positional parameters and the anisotropic temperature factors of all non- $\mathrm{H}$ atoms were refined. $\mathrm{H}$ atoms were geometrically located and their coordinates were refined riding on their parent atoms. In all the cases, the maximum residual electron density was located near to heavy atoms. The function minimized was $\left\{\Sigma\left[\omega\left(F_{o}{ }^{2}-F_{c}{ }^{2}\right)^{2}\right] / \Sigma\left[\omega\left(F_{o}{ }^{2}\right)^{2}\right]\right\}^{1 / 2}$ where $\omega=1 /\left[\sigma^{2}\left(\mathrm{~F}_{o}{ }^{2}\right)+\right.$ $\left.(a P)^{2}+b P\right]\left(a\right.$ and $b$ values are collected in Table 1) with $\sigma\left(F_{o}^{2}\right)$ from counting statistics and $P=\left[\operatorname{Max}\left(F_{o}^{2}, 0\right)+2 F_{c}^{2}\right] / 3$. Atomic scattering factors were taken from the International Tables for X-Ray Crystallography [19]. Geometrical calculations were made with PARST [20]. The crystallographic plots were made with ORTEP-3 [17]. 
Table 1. Crystallographic data for compounds 4a-c.

\begin{tabular}{|c|c|c|c|}
\hline & $4 \mathbf{a}$ & $4 b$ & $4 c$ \\
\hline Empirical formula & $\mathrm{C}_{25} \mathrm{H}_{25} \mathrm{O}_{3} \mathrm{FePS}$ & $\mathrm{C}_{27} \mathrm{H}_{29} \mathrm{O}_{3} \mathrm{FePS}$ & $\mathrm{C}_{25} \mathrm{H}_{37} \mathrm{O}_{3} \mathrm{FePS}$ \\
\hline Formula weight & 492.33 & 520.38 & 504.42 \\
\hline Temperature $[\mathrm{K}]$ & 140 & 151 & 150 \\
\hline Wavelength [Å] & 1.54184 & 1.54184 & 1.54184 \\
\hline Crystal system & Triclinic & Triclinic & Orthorhombic \\
\hline Space group & $P-1$ & $P-1$ & Pbca \\
\hline \multicolumn{4}{|l|}{ Unit cell dimensions } \\
\hline $\mathrm{a}[\AA]$ & $10.9917(5)$ & $11.4744(5)$ & $15.3053(2)$ \\
\hline $\mathrm{b}[\AA]$ & $12.6897(5)$ & $12.2673(3)$ & $17.5315(2)$ \\
\hline$c[\AA]$ & $16.5947(8)$ & $17.9299(7)$ & $18.3740(2)$ \\
\hline$\alpha\left[^{\circ}\right]$ & $80.364(4)$ & $85.520(3)$ & 90 \\
\hline$\beta\left[^{\circ}\right]$ & $77.637(4)$ & $78.453(3)$ & 90 \\
\hline$\gamma\left[^{\circ}\right]$ & $89.951(4)$ & $89.841(3)$ & 90 \\
\hline Volume $\left[\AA^{3}\right]$ & $2227.61(18)$ & $2464.96(16)$ & $4930.20(10)$ \\
\hline $\mathrm{Z}$ & 4 & 4 & 8 \\
\hline pcalcd $\left[\mathrm{g} / \mathrm{cm}^{3}\right]$ & 1.468 & 1.402 & 1.359 \\
\hline$\mu\left[\mathrm{mm}^{-1}\right]$ & 7.187 & 6.525 & 6.496 \\
\hline $\mathrm{F}(000)$ & 1024 & 1088 & 2144 \\
\hline Crystal size $[\mathrm{mm}]$ & $0.16 \times 0.13 \times 0.08$ & $0.11 \times 0.10 \times 0.09$ & $0.40 \times 0.38 \times 0.26$ \\
\hline Range for data collection $\left(\Theta,{ }^{\circ}\right)$ & 3.535 to 69.637 & 3.614 to 69.779 & 4.528 to 69.699 \\
\hline \multirow[t]{3}{*}{ Index ranges } & $-13 \leq \mathrm{h} \leq 11$ & $-13 \leq \mathrm{h} \leq 13$ & $-18 \leq \mathrm{h} \leq 18$ \\
\hline & $-15 \leq \mathrm{k} \leq 14$ & $-11 \leq \mathrm{k} \leq 14$ & $-21 \leq \mathrm{k} \leq 19$ \\
\hline & $-19 \leq 1 \leq 20$ & $-21 \leq 1 \leq 21$ & $-17 \leq 1 \leq 22$ \\
\hline Reflections collected & 20107 & 22854 & 23278 \\
\hline Independent reflections & 8252 & 9117 & 4597 \\
\hline Max. and min. transmission & 0.597 and 0.393 & 0.534 and 0.591 & 0.181 and 0.283 \\
\hline Data / restraints / parameters & 8252 / 0 / 627 & 9117 / 0 / 667 & 4597 / 0 / 314 \\
\hline Goodness-of-fit on $\mathrm{F}^{2}$ & 1.049 & 1.027 & 1.037 \\
\hline Weight function $(a, b)$ & $0.0452,1.5266$ & $0.0419,0.7617$ & $0.0400,2.3263$ \\
\hline$R 1[\mathrm{I}>2 \sigma(\mathrm{I})]$ & 0.0365 & 0.0300 & 0.0278 \\
\hline$w R 2[\mathrm{I}>2 \sigma(\mathrm{I})]$ & 0.0926 & 0.0766 & 0.0713 \\
\hline$R 1$ (all data) & 0.0399 & $\mathrm{R} 1=0.0330$ & $\mathrm{R} 1=0.0302$ \\
\hline$w R 2$ (all data) & 0.0953 & 0.0789 & 0.0731 \\
\hline Largest diff. peak \& hole $\left[\mathrm{e} \AA^{-3}\right]$ & 0.444 and -0.507 & 0.518 and -0.387 & 0.379 and -0.384 \\
\hline
\end{tabular}


CCDC 1576847 (4a), 1576848 (4b) and 1576849 (4c) contain the supplementary crystallographic data for this paper. These data can be obtained free of charge from The Cambridge Crystallographic Data Centre via www.ccdc.cam.ac.uk/data_request/cif

\section{Results and discussion}

The synthetic route employed for the preparation of the novel ferrocenylphosphino sulfonate derivatives $\left(\eta^{5}-\mathrm{C}_{5} \mathrm{H}_{3} \mathrm{PPh}_{2}\left(\mathrm{SO}_{3} i-\mathrm{Pr}\right)\right) \mathrm{Fe}\left(\eta^{5}-\mathrm{C}_{5} \mathrm{H}_{5}\right)(\mathrm{R}=\mathrm{Ph}(\mathbf{4 a}), p$-Tol (4b), Cy (4c)) is shown in Scheme 1. It starts from the $p$-toluidinium ferrocene sulfonate salt $\mathbf{1}$, readily accessible in gram scale by reaction of ferrocene with chlorosulfonic acid and further treatment with $p$-toluidine, as described by Schlögl and co-workers [10]. Following known chemistry, compound $\mathbf{1}$ was subsequently transformed into ferrocenesulfonyl chloride $\mathbf{2}$ [10] and the iso-propyl ferrocene sulfonate $\mathbf{3}$ [9]. Finally, selective ortho-metalation of $\mathbf{3}$ with sec-BuLi, and subsequent quenching with the appropriate chlorophosphine, afforded 4a-c.
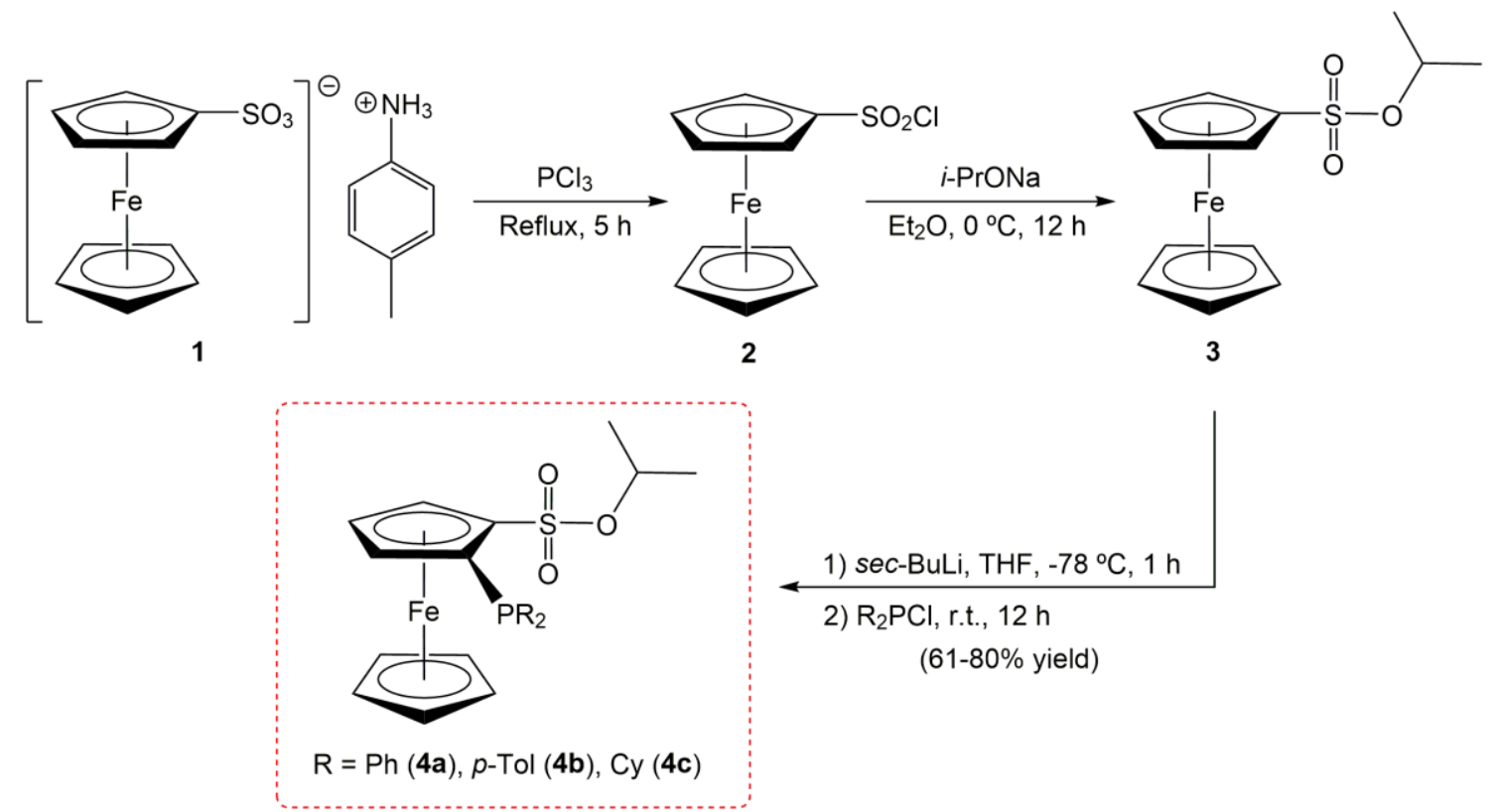

1) sec-BuLi, THF, $-78^{\circ} \mathrm{C}, 1 \mathrm{~h}$

2) $\mathrm{R}_{2} \mathrm{PCl}$, r.t., $12 \mathrm{~h}$

$(61-80 \%$ yield $)$

Scheme 1. Synthetic pathway employed for the preparation of compounds 4a-c. 
Compounds 4a-c, isolated as yellow-orange solids in $61-80 \%$ yield after chromatographic purification, were characterized by means of multinuclear NMR spectroscopy $\left({ }^{31} \mathrm{P}\left\{{ }^{1} \mathrm{H}\right\},{ }^{1} \mathrm{H}\right.$ and $\left.{ }^{13} \mathrm{C}\left\{{ }^{1} \mathrm{H}\right\}\right)$, elemental analysis and mass spectra, the data obtained being in complete accord with the proposed formulations (details are given in the Experimental section). In particular, as a consequence of the planar chirality associated to these molecules due to the asymmetric 1,2-disubstitution of one of the $\mathrm{Cp}$ rings, two set of signals were observed in the ${ }^{1} \mathrm{H}$ and ${ }^{13} \mathrm{C}\left\{{ }^{1} \mathrm{H}\right\}$ NMR spectra for the $\mathrm{R}$ substituents of the phosphino groups, as well as for the diastereotopic methyl groups of the $i$-propyl moiety (i.e. two doublet signals $\left({ }^{3} J_{\mathrm{HH}}=6.2 \mathrm{~Hz}\right)$ in the ${ }^{1} \mathrm{H}$ NMR spectrum at $\delta_{\mathrm{H}}$ 0.86-1.41 ppm, and two singlets in the ${ }^{13} \mathrm{C}\left\{{ }^{1} \mathrm{H}\right\}$ one at $\left.\delta_{\mathrm{C}} 21.3-23.6 \mathrm{ppm}\right)$. On the other hand, the binding of the $\mathrm{PR}_{2}$ groups to the ferrocenyl skeleton was clearly evidenced in the ${ }^{31} \mathrm{P}\left\{{ }^{1} \mathrm{H}\right\}$ NMR spectra by the appearance of singlet signals at $\delta_{\mathrm{P}}-22.0$ (4a), -25.0 (4b) and -12.0 (4c) ppm, strongly shielded in comparison to those of the starting chlorophosphines $\left(\delta_{\mathrm{P}} 81.5\left(\mathrm{Ph}_{2} \mathrm{PCl}\right), 83.6\left(p-\mathrm{Tol}_{2} \mathrm{PCl}\right)\right.$ and $128.8\left(\mathrm{Cy}_{2} \mathrm{PCl}\right)$ ppm).

Moreover, the structures the ferrocenylphosphino sulfonates 4a-c could be determined by single-crystal X-ray diffraction, which confirmed the 1,2-substitution of one of the cyclopentadienyl rings with the phosphine and $i$-propylsulfonate moieties. ORTEP-type views of the molecules are shown in Figure 2, while selected bond distances and angles are collected in Table 2. Compounds $\mathbf{4 a}$ and $\mathbf{4 b}$ crystallize in the triclinic crystal system (P-1 space group) and the crystals measured contained, in both cases, two independent molecules in the asymmetric unit, differing mainly on the conformation adopted by the $\mathrm{SO}_{3} i$-Pr groups (for brevity, only one of each conformer is represented in Figure 2 and only its bond distances and angles are presented in Table 2). 
In contrast, the dicyclohexylphosphino derivative $\mathbf{4 c}$ crystallizes in the orthorhombic system (Pbca space group) and only one molecule was present in the asymmetric unit.

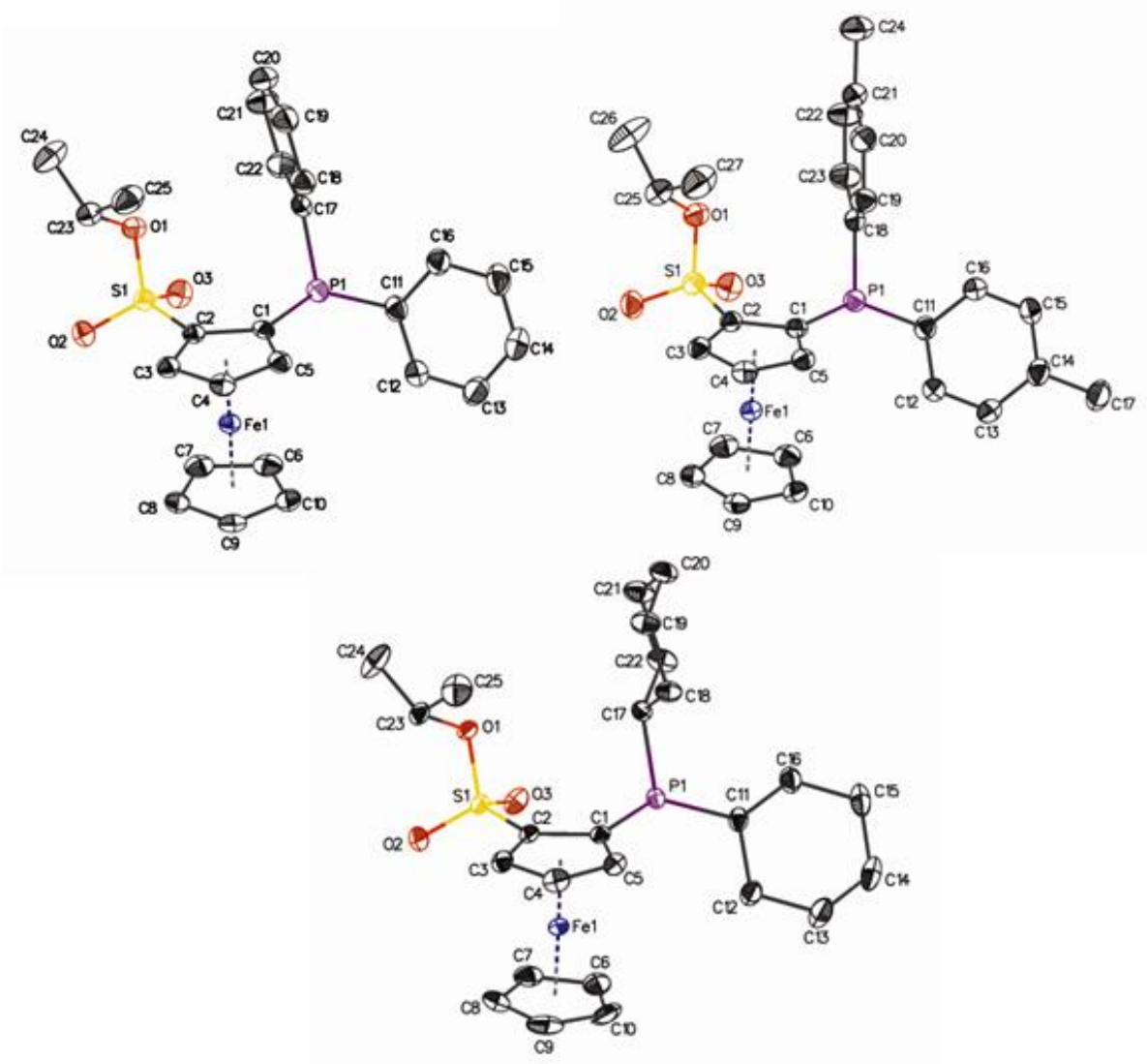

Figure 2. ORTEP-type views of the structures of compounds $\mathbf{4 a}$ (top left), $\mathbf{4 b}$ (top right) and $\mathbf{4 c}$ (bottom) showing the crystallographic labelling schemes. Hydrogen atoms have been omitted for clarity. Thermal ellipsoids are drawn ate the $30 \%$ probability level.

The cyclopentadienyl rings are in an almost eclipsed conformation in the three structures, as indicated by the torsion angle $\mathrm{C}(4)-\mathrm{C}^{*}-\mathrm{C}^{* *}-\mathrm{C}(9)$ which show values ranging from $0.45^{\circ}$ to $5.31^{\circ}$. The phosphino and sulfonate groups are linked to the $\mathrm{Cp}$ ring with $\mathrm{C}(1)-\mathrm{P}(1)$ and $\mathrm{C}(2)-\mathrm{S}(1)$ bond distances of $c a .1 .83 \AA$ and $1.74 \AA$, respectively, being both heteroatoms almost coplanar with the five-membered ring carbocycle (maximum deviation from the mean CpPS plane of $0.026 \AA$ for $\mathrm{C}(2)$ in $\mathbf{4 a}$, $0.025 \AA$ for $\mathrm{C}(2)$ in $\mathbf{4 b}$ and $0.037 \AA$ for $\mathrm{P}(1)$ in $\mathbf{4 c})$. This bonding parameters are 
comparable to those found by Metallinos and Snieckus in the solid-state X-ray crystal structure of the closely related ferrocenylphosphino sulfonate $\left(\eta^{5}-\mathrm{C}_{5} \mathrm{H}_{3} \mathrm{PPh}_{2}\left(\mathrm{SO}_{3}-(-)-\right.\right.$ menthyl) $) \mathrm{Fe}\left(\eta^{5}-\mathrm{C}_{5} \mathrm{H}_{5}\right)(\mathbf{B}$ in Figure 1) [9].

Table 2. Selected bond distances $(\AA)$ and angles $\left({ }^{\circ}\right)$ for compounds $4 \mathbf{a}-\mathbf{c}$.

\begin{tabular}{|c|c|c|c|}
\hline & $4 a$ & $4 b$ & $4 c$ \\
\hline & \multicolumn{3}{|c|}{ Bond Lengths } \\
\hline $\mathrm{Fe}-\mathrm{C}^{* a}$ & $1.6443(3)$ & $1.6443(3)$ & $1.6400(2)$ \\
\hline $\mathrm{Fe}-\mathrm{C} * * a$ & $1.6547(3)$ & $1.6576(3)$ & $1.6538(2)$ \\
\hline $\mathrm{P}(1)-\mathrm{C}(1)$ & $1.838(2)$ & $1.835(2)$ & $1.837(2)$ \\
\hline$P(1)-C(11)$ & $1.841(2)$ & $1.837(2)$ & $1.864(2)$ \\
\hline $\mathrm{P}(1)-\mathrm{C}(17)^{b}$ & $1.837(3)$ & $1.834(2)$ & $1.875(2)$ \\
\hline$C(2)-S(1)$ & $1.742(2)$ & $1.739(2)$ & $1.741(2)$ \\
\hline $\mathrm{S}(1)-\mathrm{O}(1)$ & $1.567(2)$ & $1.561(1)$ & $1.575(1)$ \\
\hline $\mathrm{S}(1)-\mathrm{O}(2)$ & $1.431(2)$ & $1.425(1)$ & $1.430(1)$ \\
\hline \multirow[t]{2}{*}{$\mathrm{S}(1)-\mathrm{O}(3)$} & $1.427(2)$ & $1.433(1)$ & $1.424(1)$ \\
\hline & \multicolumn{3}{|c|}{ Bond Angles } \\
\hline $\mathrm{C}^{*}-\mathrm{Fe}-\mathrm{C}^{* * a}$ & $176.76(3)$ & $176.86(2)$ & $178.12(2)$ \\
\hline $\mathrm{C}(1)-\mathrm{P}(1)-\mathrm{C}(11)$ & $99.4(1)$ & $101.74(8)$ & $102.68(7)$ \\
\hline $\mathrm{C}(1)-\mathrm{P}(1)-\mathrm{C}(17)^{c}$ & $97.9(1)$ & $98.51(8)$ & $95.66(7)$ \\
\hline $\mathrm{C}(11)-\mathrm{P}(1)-\mathrm{C}(17)^{d}$ & $104.1(1)$ & $101.29(8)$ & $104.82(7)$ \\
\hline $\mathrm{C}(2)-\mathrm{S}(1)-\mathrm{O}(1)$ & $103.9(1)$ & $104.18(8)$ & $104.24(6)$ \\
\hline $\mathrm{C}(2)-\mathrm{S}(1)-\mathrm{O}(2)$ & $108.3(1)$ & $108.19(8)$ & $108.20(7)$ \\
\hline $\mathrm{C}(2)-\mathrm{S}(1)-\mathrm{O}(3)$ & $109.9(1)$ & $110.03(8)$ & $109.89(7)$ \\
\hline $\mathrm{O}(1)-\mathrm{S}(1)-\mathrm{O}(2)$ & $109.8(1)$ & $110.69(8)$ & $109.18(6)$ \\
\hline $\mathrm{O}(1)-\mathrm{S}(1)-\mathrm{O}(3)$ & $104.6(1)$ & $104.17(8)$ & $104.20(7)$ \\
\hline $\mathrm{O}(2)-\mathrm{S}(1)-\mathrm{O}(3)$ & 119.2(1) & $118.63(9)$ & $119.98(7)$ \\
\hline
\end{tabular}

${ }^{a} \mathrm{C}^{*}$ and $\mathrm{C}^{* *}$ denote the centroids of the cyclopentadienyl rings (from $\mathrm{C}(1)$ to $\mathrm{C}(5)$ and from $\mathrm{C}(6)$ to $\mathrm{C}(10)$, respectively). ${ }^{b} \mathrm{P}(1)-\mathrm{C}(18)$ in the case of compound $\mathbf{2} \mathbf{b} .{ }^{c} \mathrm{C}(1)-\mathrm{P}(1)$ $\mathrm{C}(18)$ in the case of $\mathbf{2 b} .{ }^{d} \mathrm{C}(11)-\mathrm{P}(1)-\mathrm{C}(18)$ in the case of $\mathbf{2} \mathbf{b}$. 
The sum of the bond angles about the phosphorus atoms reflect their pyramidalization, i.e. $301.40^{\circ}$ for $\mathbf{4 a}, 301.54^{\circ}$ for $\mathbf{4 b}$ and $303.16^{\circ}$ for $\mathbf{4 c}$. In addition, these values are very similar to those reported, for example, by Štěpnička and Císařová for $\quad 1^{\prime}$-bromo-1-(diphenylphosphino)ferrocene $\quad\left(303.8^{\circ}\right) \quad[21]$ and 1'-bromo-1(dicyclohexylphosphino)ferrocene $\left(305.5^{\circ}\right)$ [22], which indicate that the presence of the $i$-propylsulfonate moiety in ortho position has not an important effect over the phosphine group. On the other hand, the $\mathrm{SO}_{3} i$-Pr group present the typical parameters of a tetrahedral sulphur atom, with angles ranging from $104.17(8)^{\circ}$ to $119.98(7)^{\circ}$ (see Table 2). The sulphur-oxygen bond distances observed in the three structures fall also within the expected range for single $(\mathrm{S}(1)-\mathrm{O}(1))$ and double $(\mathrm{S}(1)-\mathrm{O}(2)$ and $\mathrm{S}(1)-\mathrm{O}(3))$ bonds [23].

Once characterized, we then carried out a preliminary study of the potential utility of 4a-c as ligands for aqueous catalysis. In particular, we focused on the rutheniumcatalyzed arylation of 2-phenylpyridine. We would like to stress in this point that the metal-catalyzed arylation of organic molecules with aryl halides, via direct activation of unreactive $\mathrm{C}\left(\mathrm{sp}^{2}\right)-\mathrm{H}$ bonds, has emerged in recent years as an efficient methodology for $\mathrm{C}\left(\mathrm{sp}^{2}\right)-\mathrm{C}\left(\mathrm{sp}^{2}\right)$ bond formation, providing an appealing and greener alternative to traditional cross-coupling processes using stoichiometric amounts of organometallic reagents [24]. In this regard, after the breakthrough report of Murai on $\mathrm{Ru}(0)$-catalyzed ketone-directed ortho-C-H activation/alkylation of aromatic systems with olefins [25], and the first examples of direct ortho-arylations of 2-phenylpyridine and arylimines with arylbromides using a ruthenium(II)- $\mathrm{PPh}_{3}$ catalyst described by Oi and Inoue [26], the use of low-cost ruthenium-based catalysts (particularly $\mathrm{Ru}(\mathrm{II})$ species) has tremendously contributed to the discovery of new C-C coupling reactions by directing- 
group-assisted $\mathrm{C}\left(\mathrm{sp}^{2}\right)-\mathrm{H}$ activation processes (Scheme 2) [27]. Although the vast majority of the reported work has been performed in classical organic media, Dixneuf and co-workers nicely demonstrated that these $\mathrm{Ru}(\mathrm{II})$-catalyzed $\mathrm{C}-\mathrm{H}$ bond functionalization reactions are also compatible with the use of water as solvent, thus contributing to make this chemistry even greener [28].

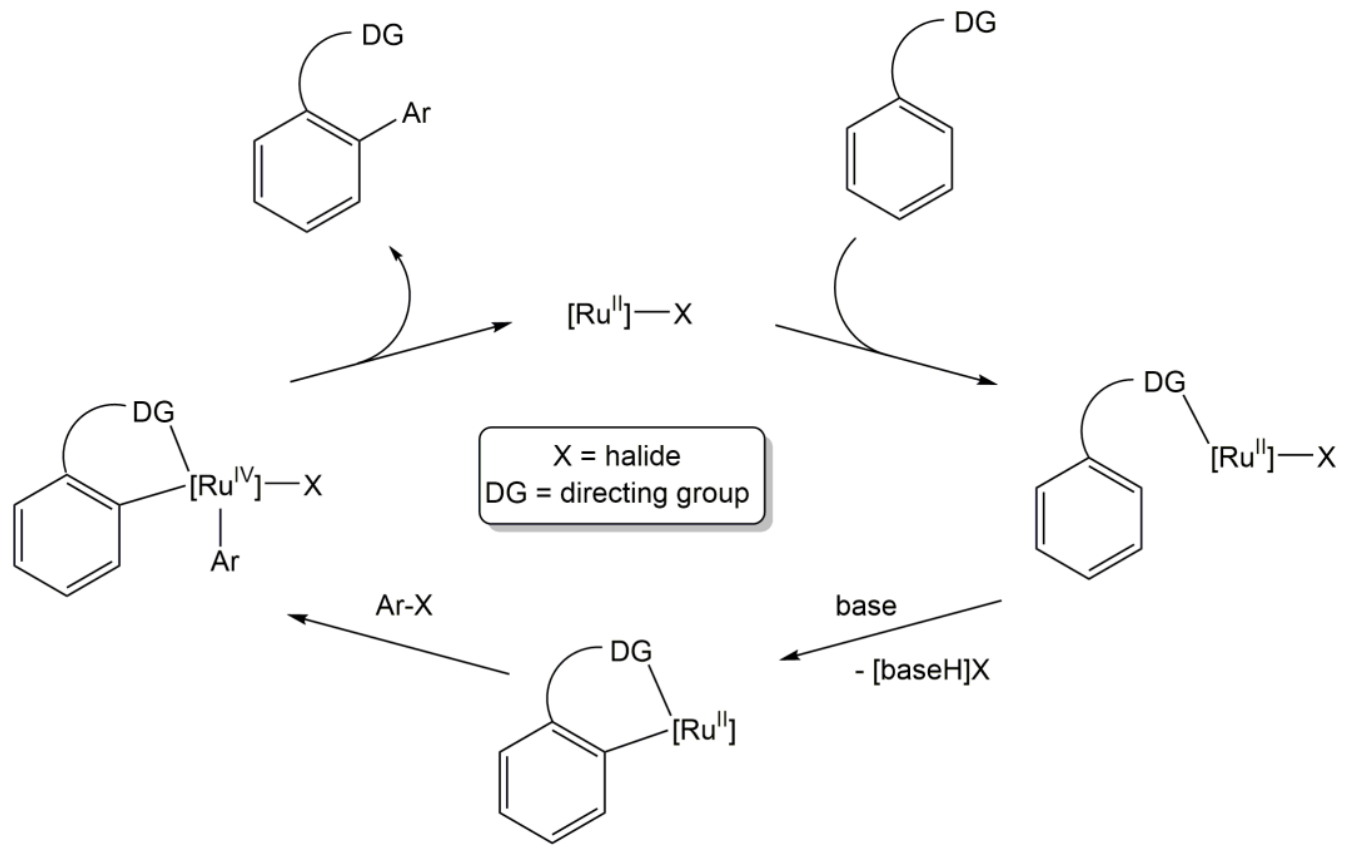

Scheme 2. Proposed mechanism for the $\mathrm{Ru}(\mathrm{II})$-catalyzed $\mathrm{C}\left(\mathrm{sp}^{2}\right)-\mathrm{C}\left(\mathrm{sp}^{2}\right)$ bond forming reactions.

In our initial studies, we investigated the phenylation of 2-phenylpyridine with a slight excess of bromobenzene (1.5 equiv.), employing $\mathrm{K}_{2} \mathrm{CO}_{3}$ (1 equiv.) as the base, the dimeric precursor $\left[\left\{\operatorname{RuCl}(\mu-\mathrm{Cl})\left(\eta^{6}-p \text {-cymene }\right)\right\}_{2}\right](2.5 \mathrm{~mol} \%$; i.e. $5 \mathrm{~mol} \%$ of $\mathrm{Ru})$ as the $\mathrm{Ru}(\mathrm{II})$ source, and water as solvent. As shown in entries 1-3 of Table 3, when the mixture was heated at $100{ }^{\circ} \mathrm{C}$ for $24 \mathrm{~h}$ in the presence of ligands $4 \mathbf{a}-\mathrm{c}$ ( $5 \mathrm{~mol} \%$; i.e. 1 equiv. per $\mathrm{Ru}$ atom), very different results were obtained as a function of the substituents present in the phosphino group of the ferrocenyl ligand. Thus, while in the case of dicyclohexyl-substituted derivative $\mathbf{4 c}$ a very low conversion of the starting 2- 
phenylpyridine was observed (entry 3), its aromatic counterparts $\mathbf{4 a - b}$ proved to be much more effective leading to conversions higher than $79 \%$ (entries 1-2). The reactions exclusively gave the mono- and diarylated derivatives $\mathbf{5}$ and $\mathbf{6}$, respectively, with the former being the predominant one in both cases, and without formation of sideproducts.

Table 3. Ruthenium-catalyzed arylation of 2-phenylpyridine in water employing the ferrocenylphosphino sulfonates $\mathbf{4 a - c}$ as ligands. ${ }^{a}$

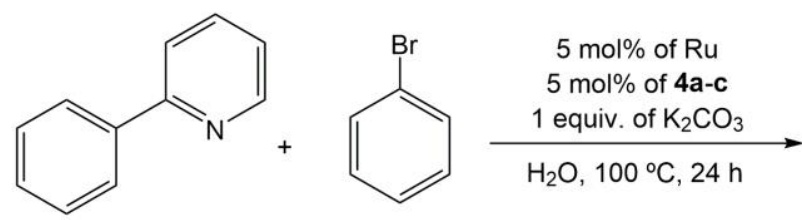<smiles>c1ccc(-c2ccccc2-c2ccccn2)cc1</smiles><smiles>c1ccc(-c2cccc(-c3ccccc3)c2-c2ccccn2)cc1</smiles>

\begin{tabular}{|c|c|c|c|c|}
\hline Entry & $\mathrm{Ru}$ precursor & Ligand & Yield $(\%)^{\mathrm{b}}$ & $5: 6$ ratio $^{b}$ \\
\hline 1 & {$\left[\left\{\operatorname{RuCl}(\mu-\mathrm{Cl})\left(\eta^{6}-p \text {-cymene }\right)\right\}_{2}\right]$} & $\mathbf{4 a}$ & 88 & $52: 36$ \\
\hline 2 & {$\left[\left\{\operatorname{RuCl}(\mu-\mathrm{Cl})\left(\eta^{6}-p \text {-cymene }\right)\right\}_{2}\right]$} & $4 b$ & 79 & $60: 19$ \\
\hline 3 & {$\left[\left\{\operatorname{RuCl}(\mu-\mathrm{Cl})\left(\eta^{6}-p \text {-cymene }\right)\right\}_{2}\right]$} & $4 c$ & 29 & $20: 9$ \\
\hline $4^{c}$ & {$\left[\left\{\operatorname{RuCl}(\mu-\mathrm{Cl})\left(\eta^{6}-p \text {-cymene }\right)\right\}_{2}\right]$} & $4 b$ & 44 & $40: 4$ \\
\hline 5 & {$\left[\left\{\mathrm{RuCl}(\mu-\mathrm{Cl})\left(\eta^{6}-\mathrm{C}_{6} \mathrm{H}_{6}\right)\right\}_{2}\right]$} & $4 b$ & 68 & $43: 15$ \\
\hline 6 & {$\left[\left\{\operatorname{RuCl}(\mu-\mathrm{Cl})\left(\eta^{6}-\mathrm{C}_{6} \mathrm{Me}_{6}\right)\right\}_{2}\right]$} & $4 b$ & 64 & $46: 18$ \\
\hline 7 & {$\left[\mathrm{RuCl}_{2}\left(\mathrm{PPh}_{3}\right)_{3}\right]$} & $4 b$ & 25 & $23: 2$ \\
\hline 8 & cis- $\left[\mathrm{RuCl}_{2}(\mathrm{DMSO})_{4}\right]$ & $4 b$ & 10 & 10:0 \\
\hline 9 & {$\left[\left\{\operatorname{RuCl}(\mu-\mathrm{Cl})\left(\eta^{6}-p \text {-cymene }\right)\right\}_{2}\right]$} & TPPMS & 94 & $38: 56$ \\
\hline
\end{tabular}

${ }^{a}$ Reactions performed under Ar atmosphere with $0.5 \mathrm{mmol}$ of 2-phenylpyridine, $0.75 \mathrm{mmol}$ of bromobenzene, $0.5 \mathrm{mmol}$ of $\mathrm{K}_{2} \mathrm{CO}_{3}, 5 \mathrm{~mol} \%$ of $\mathrm{Ru}$ and the corresponding ligand, and $1 \mathrm{~mL}$ of water at $100{ }^{\circ} \mathrm{C} .{ }^{b}$ Determined by $1 \mathrm{H}$ NMR spectroscopy. ${ }^{c}$ Reaction performed in toluene at 120 ${ }^{\circ} \mathrm{C}$ for $24 \mathrm{~h}$. 
From a regioselectivity point of view, the most interesting result of this initial screening was that obtained with the ferrocenylphosphino sulfonate ligand $\mathbf{4 b}$ since the monoarylated derivative 5 was largely the major reaction product (entry 2) [29]. In this respect, it is worth noting that selective monoarylations are in general achieved only when one ortho substituent is already present in the substrate or when one of the ortho$\mathrm{C}-\mathrm{H}$ bonds is sterically protected by a bulky substituent in meta position, representing one of the more important challenges in the catalytic reaction under study [26-28]. Interestingly, when the same reaction was performed in toluene at $120{ }^{\circ} \mathrm{C}$, the monoarylated product 5 was again predominantly formed (entry 4). However, the effectiveness of the process was in this case lower, thus indicating a beneficial effect of using water as the reaction medium. Further studies with ligand $\mathbf{4 b}$ and different ruthenium(II) sources also confirmed the preference of this ligand the towards monoarylation of 2-phenylpyridine (entries 5-8), although in no case the result obtained with $\left[\left\{\operatorname{RuCl}(\mu-\mathrm{Cl})\left(\eta^{6}-p \text {-cymene }\right)\right\}_{2}\right]$ could be improved.

Finally, for comparative purposes, we carried out the arylation reaction of 2phenylpyridine with complex $\left[\left\{\operatorname{RuCl}(\mu-\mathrm{Cl})\left(\eta^{6}-p \text {-cymene }\right)\right\}_{2}\right]$ in presence of the wellknown sulfonated phosphine TPPMS. As shown in entry 9, although this catalytic system led to a higher conversion, its selectivity was much lower than when using the ferrocenylphoshino sulfonate ligand $\mathbf{4 b}$ (entry 9 vs 2 ), further forming the diarylated derivative $\mathbf{6}$ as the major reaction product. The presence of the ferrocenyl skeleton in the ligand structure seems therefore to be relevant to achieve a high degree of selectivity towards the monoarylation.

\section{Conclusions}


In summary, in this contribution we have presented the synthesis of three new ferrocenylphoshino sulfonates, as well as their unambiguous characterization by singlecrystal X-ray diffraction techniques. Preliminary studies also demonstrated the utility of these species as auxiliary ligands in the $\mathrm{Ru}(\mathrm{II})$-catalyzed selective ortho monoarylation of 2-phenylpyridine in water. To the best of our knowledge, the work presented herein represent the first application of this unexploited class of ferrocenylphosphines in aqueous catalysis. Further studies aiming at exploring the coordination chemistry of these ligands in different $\mathrm{Ru}(\mathrm{II})$ fragments, and the scope of the catalytic $\mathrm{C}-\mathrm{H}$ arylation process, are now in progress in our laboratories and will be the subject of a future contribution.

\section{Acknowledgments}

D. Sierra and C. Contreras acknowledge to FONDECYT Chile for financial support (Grant 11140466). V. Cadierno and J. Francos are indebted to MINECO of Spain (Projects CTQ2016-81797-REDC and CTQ2016-75986-P) and Gobierno del Principado de Asturias (Project GRUPIN14-006) for funding. J. Gómez acknowledge to DI-PUCV for financial support.

\section{References}

[1] (a) P. Štěpnička (Ed.), Ferrocenes: Ligands, Materials and Biomolecules, John Wiley \& Sons, Chichester, 2008; (b) R. Gómez-Arrayás, J. Adrio, J. C. Carretero, Angew. Chem. Int. Ed. 45 (2006) 7674-7715; (c) R. C. J. Atkinson, V. C. Gibson, N. J. Long, Chem. Soc. Rev. 33 (2004) 313-328; (d) A. Togni, T. Hayashi (Eds.), Ferrocenes: Homogeneous Catalysis, Organic Synthesis and Materials Science, Wiley-VCH, Weinheim, 1995. 
[2] (a) P. H. Dixneuf, V. Cadierno (Eds.), Metal-Catalyzed Reactions in Water, Wiley-VCH, Weinheim, 2013; (b) B. Cornils, W. A. Herrmann (Eds.), AqueousPhase Organometallic Catalysis ( $2^{\text {nd }}$ Ed), Wiley-VCH, Weinheim, 2004; (c) I. T. Horváth, F. Joó (Eds.), Aqueous Organometallic Chemistry and Catalysis, Kluwer Academic Publishers, Dordrecht, 1995.

[3] K. H. Shaughnessy, Chem. Rev. 109 (2009) 643-710.

[4] See, for example: (a) J. Schulz, F. Horký, I. Císařová, P. Štěpnička, Catalysts 7 (2017) 167; (b) O. Bárta, I. Císařová, P. Štěpnička, Eur. J. Inorg. Chem. (2017) 489-495; (c) K. Škoch, I. Císařová, P. Štěpnička, Organometallics 35 (2016) 3378-3387; (d) J. Schulz, I. Císařová, P. Štěpnička, Organometallics 31 (2012) 729-738; (e) J. Tauchman, I. Císařová, P. Štěpnička, Organometallics 28 (2009) 3288-3302.

[5] A. A. Karasik, R. N. Nuamov, R. Sommer, O. G. Sommer, O. G. Sinyashin, E. Hey-Hawkins, Polyhedron 21 (2002) 2251-2256.

[6] N. Pinault, D. W. Bruce, Coord. Chem. Rev. 241 (2003) 1-25.

[7] See, for example: K. Chanawanno, C. Holstrom, L. A. Crandall, H. Dodge, V. N. Nemykin, R. S. Herrick, C. J. Ziegler, Dalton Trans. 45 (2016) 14320-14326 and referenced cited therein.

[8] (a) M. Chen, B. Yang, C. Chen. Angew. Chem. Int. Ed. 54 (2015) 15520-15524.

(b) C. Chen, T. M. J. Anselment, R. Frohlich, B. Rieger, G. Kehr, G. Erker, Organometallics 30 (2011) 5248-5257.

[9] C. Metallinos, V. Snieckus. Org. Lett. 4 (2002) 1935-1938.

[10] H. Falk, C. Krasa, K. Schlögl, Monasth. Chem. 100 (1969) 1552-1563.

[11] M. A. Bennett, T.-N. Huang, T. W. Matheson, A. K. Smith, Inorg. Synth. 21 (1982) 74-78. 
[12] M. A. Bennett, A. K. Smith, J. Chem. Soc., Dalton Trans. (1974) 233-241.

[13] P. S. Hallman, T. A. Stephenson, G. Wilkinson, Inorg. Synth. 12 (1970) 237240.

[14] I. P. Evans, A. Spencer, G. Wilkinson, J. Chem. Soc., Dalton Trans. (1973) 204209.

[15] W. L. F. Armarego, C. L. L. Chai, Purification of Laboratory Chemicals $\left(5^{\text {th }}\right.$ Ed.), Butterworth-Heinemann, Oxford, 2003.

[16] CrysAlisPro CCD \& CrysAlisPro RED, Oxford Diffraction Ltd., Oxford, UK, 2008.

[17] L. J. Farrugia, J. Appl. Cryst. 45 (2012) 849-854.

[18] G. M. Sheldrick, Acta Cryst. C71 (2015) 3-8.

[19] A. J. C. Wilson (Ed.), International Tables for X-Ray Crystallography, vol. C, Kluwer Academic Publishers, Dordrecht, The Netherlands, 1992.

[20] M. Nardelli, Comput. Chem. 7 (1983) 95-98.

[21] P. Štěpnička, I. Císařová, J. Organomet. Chem. 691 (2006) 2863-2871.

[22] P. Štěpnička, I. Císařová. Dalton Trans. 42 (2013) 3373-3389.

[23] F. H. Allen, O. Kennard, D. G. Watson, L. Brammer, A. G. Orpen, R. Taylor, J. Chem. Soc., Perkin Trans. 2 (1987) S1-S19.

[24] See, for example: (a) J. J. Li (Ed.), C-H Bond Activation in Organic Synthesis, CRC Press, Boca Ratón, 2015; (b) J.-Q. Yu, Z. Shi (Eds.), C-H Activation, Springer, Berlin, 2010.

[25] S. Murai, F. Kakiuchi, S. Sekine, Y. Tanaka, A. Kamatani, M. Sonoda, N. Chatani, Nature 366 (1993) 529-531. 
[26] (a) S. Oi, S. Fukita, N. Hirata, N. Watanuki, S. Miyano, Y. Inoue, Org. Lett. 3 (2001) 2579-2581; (b) S. Oi, Y. Ogino, S. Fukita, Y. Inoue, Org. Lett. 4 (2002) 1783-1785.

[27] See, for example: (a) L. Ackermann, Chem. Rev. 111 (2011) 1315-1345; (b) P. B. Arockiam, C. Bruneau, P. H. Dixneuf, Chem. Rev. 112 (2012) 5879-5918; (c) L. Ackermann, Org. Process Res. Dev. 19 (2015) 260-269.

[28] (a) P. B. Arockiam, C. Fischmeister, C. Bruneau, P. H. Dixneuf, Angew. Chem. Int. Ed. 49 (2010) 6629-6632; (b) B. Li. K. Devaraj, C. Darcel, P. H. Dixneuf, Tetrahedron 68 (2012) 5179-5184; (c) P. B. Arockiam, C. Fischmeister, C. Bruneau, P. H. Dixneuf, Green Chem. 15 (2013) 67-71; (d) B. Li, P. H. Dixneuf, Chem. Soc. Rev. 42 (2013) 5744-5767.

[29] A very similar result was obtained when 4-bromoanisole, instead of bromobenzene, was employed as substrate $(77 \%$ conv. after $24 \mathrm{~h}$ with a mono/diarylation ratio of $61: 16)$. This fact seems to indicate a clear trend of this new catalytic system towards the selective ortho monoarylation. 


\section{FOR GRAPHICAL ABSTRACT USE ONLY}

\section{Novel ferrocenylphosphino sulfonates: Synthesis, crystal structure and preliminary application as ligands in aqueous catalysis}

Diego Sierra, Claudia Contreras, Javier Francos, Johana Gómez and Victorio Cadierno

The preparation of novel ferrocenylphosphino sulfonates is presented, along with their application as ligands in the ruthenium(II)-catalyzed arylation of 2-phenylpyridine water.

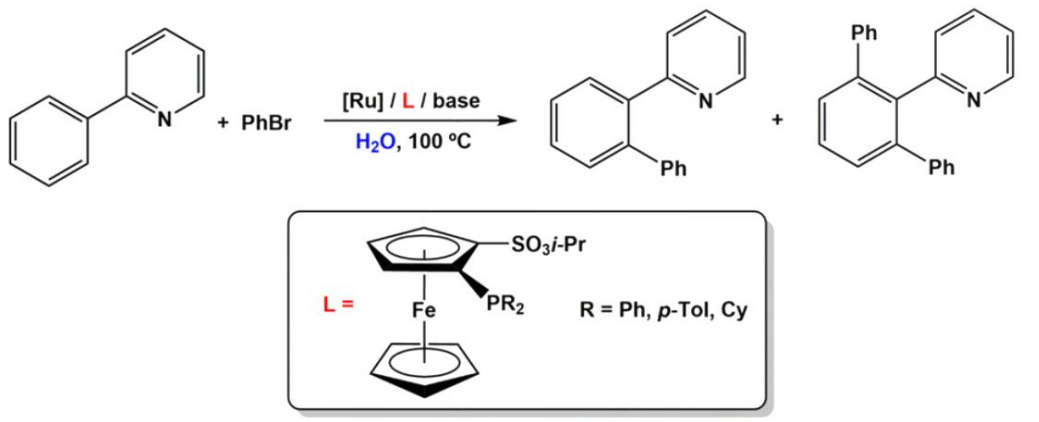




\section{Highlights}

- Three new ferrocenylphosphino sulfonates have been synthesized.

- Their structures were unambiguously confirmed by means of single-crystal Xray diffraction.

- The first application of ferrocenylphosphino sulfonates in aqueous catalysis is briefly presented. 